\section{Interpretação ambiental e envolvimento comunitário: ecoturismo como ferramenta para a conservação do boto-vermelho, Inia geoffrensis}

\author{
Fernanda Carneiro Romagnoli \\ feromagnoli@ig.com.br \\ Dissertação de Mestrado \\ Programa de Pós-Graduação em \\ Biologia de Água Doce e Pesca Interior \\ Instituto Nacional de Pesquisas da Amazônia \\ Manaus (AM) 2009
}

O turismo voltado à observação de baleias e golfinhos cresce rapidamente em todo o mundo. Esta atividade é considerada como potencial medida de conservação; no entanto, se desordenada, pode causar efeito inverso. Na Amazônia, a espécie-alvo é o boto-vermelho, Inia geoffrensis. As ameaças a esta espécie têm aumentado significativamente, o que inclui o turismo desordenado. Diante da necessidade de se adotar medidas para sua conservação, o "ecoturismo" pode ser uma ferramenta útil. Um de seus fundamentos é promover a sensibilização ambiental de turistas e moradores locais, de modo a que contribuam com a conservação. Os resultados deste estudo evidenciaram que o turismo envolvendo o boto-vermelho em duas áreas no estado do Amazonas não tem contribuído satisfatoriamente para a sensibilização desses atores. Assim, vemos uma grande, mas inexplorada oportunidade para se trabalhar a educação ambiental para a promoção da conservação deste golfinho. Por isso, foram traçadas propostas para o ordenamento do turismo envolvendo o boto-vermelho.

\section{Environmental interpretation and involvement of local residents: ecotourism as a tool in river dolphin conservation, Inia geoffrensis}

\author{
Fernanda Carneiro Romagnoli \\ feromagnoli@ig.com.br \\ Master Dissertation \\ Post-Graduate Program in Fresh Water Biology and Fishery \\ National Institute for Research in the Amazon \\ Manaus (AM) - Brazil 2009
}

Tourism aimed at observing whales and dolphin (commonly referred to as "whale watching") is growing rapidly throughout the world. This kind of tourism is often cited as having conservation potential, however when carried out improperly it can even have a negative effect. In the Amazon, the main species of aquatic mammal sought out for observational tourism is the pink river dolphin (boto in Portuguese), Inia geoffrensis. Threats to the species have increased significantly in recent years, and poorly organized tourism is considered one potential threat. The paradigm of ecotourism has been suggested as a useful tool in promoting conservation measures. This research shows that river dolphin tourism in two regions of Amazonas state in the Brazilian Amazon does not contribute in a satisfactory manner to improving conservation awareness of various local actors and the tourists themselves. Instead, we find a tremendous but poorly exploited potential to use river dolphin tourism for environmental education and conservation promotion. In this context we propose measures for better organizing river dolphin tourism in the Amazon and improving its relevance to the conservation of this emblematic and threatened species.

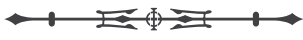

